\title{
INTRODUCTION: FOR AN EXPERIMENTAL MUSEOLOGY
}

\author{
Michael Haldrup, Marianne Achiam, and Kirsten Drotner
}

In November 2018, the National Museum of Denmark opened a small, temporary exhibition, Meet the Vikings, that attempted to create new spaces of speculation and imagination in the museum. The exhibition juxtaposed a relatively traditional showcase exhibition of gold finds from what, in popular parlance, is known as 'The Viking Age' (c. 700-1,000) in Scandinavia with oil paintings of early Danish kings and queens in addition to displays of imagined clothes and headwear and various scenographies created by reality star and fashion designer Jim Lyngvild. The exhibition followed an earlier initiative by the museum that year, Meet the Danes, which offered guided tours and various events aimed at introducing non-Danish visitors to national particularities such as biking culture, welfare politics and childcare. At the same time, the exhibition reflected the new director's ambitions of creating a museum space affording 'a sense of and demonstration that the past and the future are never given beforehand' (Blüdnikow, 2017, n.p.). Contrary to what might have been yet another small leadership initiative to strengthen the museum profile to international visitors and/or attract attention through spectacular curatorial experiments, the exhibition ignited a heated, domestic debate and critique. Did the country's most distinguished cultural-history institution abandon its time-honoured role as a guarantor of authenticated, scientific knowledge through its collaboration with a wellknown designer/reality star? Did it trivialise its unique holdings by circulating contrived, kitschy and fairytale-like and, according to some reports, nationalistic representations of the past by pandering to uneducated and ignorant users?

Without engaging with the curatorial and scientific merits of this particular exhibition, it is fair to say that the public debate surrounding its opening indicates that when choosing to experiment with their institutional roles, representational instruments and their relations to users museums are faced with a minefield of unpredictable outcomes in relation to both professional and public reception. Hence, the example quoted above clearly illuminates a growing need to more systematically 
understand, evaluate and construct how museums interact with the world around them. This interaction offers options and obstacles that are not limited to culturalhistorical museums, they also face natural-history museums, science centres, art galleries and heritage parks. In this volume, we therefore embrace an inclusive conceptualisation of museums and will refer to all of these institutions as 'museums.'

Worldwide, museums currently strive to redefine their 'art of relevance' (Simon, 2016) to the public - of which the above example merely provides anecdotal evidence. In public as well as professional debate, many of the challenges facing museums are framed in terms of various dilemmas related to the tension between the traditional role of the museum as a beacon of public enlightenment and the urgency of attracting new audiences in an increasingly consumerist experience economy. In handling these dilemmas, some museologists have recently called for 'post-critical' museologies (Dewdney et al., 2013), while others propose a strengthening of critical positions (Bishop, 2014; Shelton, 2013). With budgets under pressure and with the additional long-term financial consequences of the COVID-19 pandemic sweeping the globe from late 2019 on, museums increasingly find themselves confronted with the task of reinventing and redefining their role and relevance for society at large, thus moving beyond their classical positions as shrines of either education or entertainment. While the new museology of the 1990s (Hooper-Greenhill, 1992; Vergo, 1989) provided opportunities and tools for reflecting in general terms on the societal role played by museums as institutions and cultural producers, we argue here that we now need to hone in on more concrete conceptualisation and documentation of the everyday challenges and choices facing museums when they relate to the world around them. This argument is especially urgent, since museums must find specific solutions to these challenges and choices, and they must do so within wider social, political and economic ramifications that are rarely of their own making. The result is handling a range of very concrete dilemmas, as outlined above.

We call for an experimental museology in which museum professionals' actual practices are aligned with interdisciplinary academic discourses so as to better handle the particular dilemmas faced by museums in balancing, for example, dimensions of enlightenment and entertainment. Experimentation is of course not a new concept in museology and museum practice. Both have always to some extent relied on experimental approaches to their dissemination of knowledge, attempting to reach diverse audiences and raising questions of inclusion, diversity and rights. Through discrete experiments, museums have developed new concepts and ideas for exhibitions and communicative outreach, just as institutions have imported and crossfertilised traditions and formats from one type of museum to another. For example, cultural museums borrow ideas from science centres' traditions of audience engagement through hands-on activities just as science centres are influenced by genres and aesthetics traditionally found at art galleries' display of visual art. Moreover, museological (sub)disciplines have increasingly developed design-based approaches to develop, test and evaluate museum exhibitions and modes of communication (such as Sarah Kenderdine's Laboratory for Experimental Museology at École 
Polytechnique Fédérale de Lausanne, see Chapter 1, this volume). However, this volume offers a sustained effort to systematically identify, interrogate and reflect on experimentation as a distinct approach to museum interaction across different institutional and disciplinary boundaries in order to help advance its conceptual as well as practical appropriations.

So, rather than asking disconnected, analytical questions about digital integration, object representations or audience engagements across online and offline spaces, this volume addresses how museums may handle ongoing dilemmas by fostering change through experimentation within wider design ecologies. Our key claim is that academics, professionals and practitioners alike need to move beyond analysis. While analysis and critique are vital, they are not enough. We need to adopt experimental approaches that foreground co-design and co-creation so as to transform current, often binary, discourses and existing practices. Further, we contend that experimental museology is a way of productively aligning museum professionals' actual expertise and academic discourse so that both groups are better positioned to illuminate contingencies and optimise joint risk-taking when exploring new vistas and courses of action.

Last, but not least, this volume is premised on a holistic approach to understanding museums. We approach museums as networked nodes which, today as in the past, are in constant interaction with the surrounding world in its physical and economic as well as cultural and social dimensions. This holistic view implies an attention to how various forms of museum interaction evolve, or might evolve. Museum interaction is instigated by someone (often the museum itself), it is about something, and it is directed at someone. Yet the outcomes may differ from what was intended. So, museum interaction may be perceived as a form of dynamic communication across a range of sites and settings, involving multiple actors and media and taking many directions: from the museum to one or more groups of receivers (visitors, students, tourists, community groups, stakeholders, policymakers, funders); in dialogues between one or more museum professionals and the public; and, more rarely, from one or more receivers to the museum. As the volume chapters document, such a holistic approach is felicitous when the ambition is to not only analyse existing museum interaction, but also experimenting with its elements, their relations and boundaries.

The volume organisation reflects this holistic approach. The three volume sections - institutions, representations and users - address the key dimensions of museum interaction, or museum communication. They also highlight different traditions in handling current dilemmas, traditions that experimental museology should be mindful of when providing its answers.

\section{Institutions, representations, users}

Current debates of how museums could change their interactions with the world around them have been evident in museology and museum practice at least since the 1990s. Reflecting our observation that these interactions can be defined as 
various forms of communication, the debates can be identified to revolve around three key issues: (1) the need to redefine the role of museum institutions in relation to their users and society at large; (2) the need to recognise the nonneutrality and performative properties of representation such as displays, interfaces and learning resources; and (3) the need to re-conceptualise relations to users in the creation and dissemination of knowledge.

In terms of the institutional role of museums, recent research illuminates two rather different avenues. One is to follow neoliberal calls to define cultural institutions, including museums, as players in a competitive market of cultural consumption (Falk \& Sheppard, 2006; Rentschler \& Hede, 2015). This avenue implies that museums step up in terms of generating revenue and secure consumer satisfaction, for example through special events, entertaining exhibitions and more slick café, shop and lounge areas. Another avenue suggests that museum institutions should redefine themselves more clearly as catalysts of public value for citizen groups and communities or, even, as active agents in shaping more sustainable, just and equitable futures. Yet, as noted by Robert Janes and Richard Sandell in the introduction to their recent comprehensive review of museum activism:

[D] espite this increasing understanding of the museum as both non-neutral and active in shaping the way we perceive, think and act, there remains a persistent anxiety among museum workers in how to negotiate the opportunities and challenges this capacity for influence presents.

(Janes \& Sandell, 2019, p. 9)

Both the commodity and social-value avenues define museums in relation to factors and goals beyond the museum itself, and both involve processes of transformation. ICOM's suggestion to define museums as 'democratising, inclusive and polyphonic spaces' that 'contribute to human dignity and social justice, global equality and planetary wellbeing' (ICOM, 2019) resonates with, and may be seen as a response to, the current discussions on the need for more activist and affirmative roles of cultural institutions.

So, closely related to the contested institutional position of museums is a need to rethink the modes of representation that are traditionally defined as emblematic for the way museums present themselves to the public, and to see these modes as part of a wider field of museum communication. Acknowledging this wider field also invites explorations of a broader range of communicative modes including, for example, social media and interactive archives, community workshops and events, narrative exhibition routes, gamification of educational material, cultural festivals and co-creation with artists in residence. Importantly, museum incentives to widen their range of representations are brought about by conflicting policy discourses and practices which predate the advent of new communication technologies (Drotner et al., 2018). Yet, the massive uptake of digital technologies also in museums have catalysed communicative modes that situate time-honoured pillars of representation, such as exhibitions, within wider contexts of use. Potential and actual audiences can 
get behind the scenes online, they can interact with the 'connected museum' (Drotner \& Schrøder, 2013) in their social media feeds, and encounter signature excavations in airport lounges.

The transformations in modes of representation indicate that representations cannot simply be defined as entities encapsulating inherent information. Rather, they attain meaning and significance through communicative processes of production and reception. This relational understanding points to transformations in how museum users are defined. Visitor studies remains the mainstream tradition of analysing who comes to the museum, their individual motivations, needs and behaviour (e.g. Falk \& Dierking, 2013). This psychological approach and its experimental and quantitative methodologies are increasingly supplemented by studies drawing on sociological and cultural traditions. Here, focus is on meaningmaking as situated and dynamic socio-cultural practices dependent on contexts of application and use; and studies of these practices often rely on qualitative and explicitly interpretive methodologies. Also, the objects of interest in the sociological and cultural traditions are not, or not merely, visitors engaged in activities at a physical museum, but equally people encountering museums online, in their local communities and through media such as radio and television. Interpretive scholars often call these people audiences, a term whose primary legacy is interpretive media and communication studies (Schrøder, 2018).

Yet, there is considerable conflation of terms - visitors, audiences, guests, users, citizens - and this conflation is a clear indication that the 'receiving end' of museum communication has assumed increasing professional importance since the 1990s. This introduction applies the term user(s) in an attempt to evade the conceptual binaries of visitors and audiences dominating museum studies; but we are mindful of the fact that the term 'user' may invoke an individualistic understanding that the volume does not support. Across the different traditions, there is a growing recognition that people are committed and active knowledge producers also in their various engagements with museums and have to be studied as such. This volume offers a range of examples of how such studies may be taken as stepping-stones of experimentation which serve to challenge museums' perceptions of (intended) users and users' understanding of each other.

Taken together, the analytical dimensions of institutions, representations and users reflect the need to take a holistic approach when studying museum interaction with the surrounding world. Just as importantly, as documented above recent research trends in each of these traditions point to an increasing recognition that museums need to challenge their rationale for being in the world in a manner that goes beyond Stephen E. Weil's famous call to museums 'being for somebody' (Weil, 1999). One way to heed that challenge is to identify a third position forged beyond the institutional binaries of experience economy and public funding; the representational binaries of entertainment and enlightenment; and the user binaries of individual needs and social interpretation. Forging such a position, we argue, is facilitated through long-term experimentation that catalyses sustainable transformations of relations between and across institutions, representations and users. 


\section{An experimental museology?}

In promoting an 'experimental' approach to museology we obviously build on what has been termed the 'fourth' or post-critical wave of museology ${ }^{1}$ with its focus on exhibition design and practice. This wave is often associated with work developed at the Leicester School of Museum Studies in the United Kingdom and with the work of especially Nina Simon in the U.S.A. and their insistence on multi-vocalism, collaboration and participation (Dewdney et al., 2013; Drotner \& Schrøder, 2013; Knell et al., 2007; Macdonald, 2007; Simon, 2010). Within this line of research, the museum is sometimes suggested to be a site 'laboratory' (Heller et al., 2015; see also Kenderdine, this volume) and/or a site of experimentation within the exhibition space (Bjerregaard, 2019; Macdonald \& Basu, 2007; Tzortzi, 2015). In such spaces generative approaches 'meet' museological and disciplinary knowledge in the creation of exhibitions, encounters with users and often with a reflection on the institutional role of museum practices. Hence, Peter Bjerregaard emphasises that not only do museum exhibitions entail the capacity to generate research in and of themselves, but:

Working intensely with collections, testing ideas out in a physical environment, and relating more or less directly to a lay audience does not only tell us something new about how to make exhibitions, but may also provide us with more insights into the subject matter of the exhibition. That is, the exhibition has the potential to create a research surplus; through the making of exhibitions we are liable to learn more about the topic of the exhibition. But, (...) this research surplus does not only concern how much we know, but also involves different ways of knowing. It seems as if the making of exhibitions allows us to understand things in ways that are different to the usual textual production of research and can therefore add perspectives to more conventional cycles of research.

(Bjerregaard, 2019, pp. 1-2. See also Pierroux et al., this volume)

The 'research surplus' that Bjerregaard refers to here, is what within the field of design studies is often referred to as a particular 'designerly way of knowing' (Cross, 2007). Such knowledge production distinguishes itself from scientific and scholarly ways of knowing because it is characterised by a synthesising approach to problem-solution based on continuous iterative cycles of experience-based construction, reflection and re-construction (Cross, 2007, pp. 22-27). Following from this, we stress the need to not simply accumulate discrete examples of practical exhibition design but to systematically demonstrate the validity of cross-fertilising qualitative user studies, exhibition design, constructivist education studies and ethnographic media and communication studies in order to compare and evaluate practical design experiments on a theory-based foundation (Macdonald, 2007; Schrøder, 2018; Treagust et al., 2014).

Drawing on Bruno Latour's and Peter Weibel's exhibition (and text), Making things public (Weibel \& Latour, 2007), Binder and colleagues (Binder et al., 2011, p. 52) 
argue that design interventions and processes are marked by 'thing-ing,' by which they mean the process of materialising and constituting embodied worlds that enable users to experience and explore these worlds. Learning from this process of 'thing-ing,' understood as a purposeful staging of performative interventions (whether this staging takes the form of a museum display, a citizen workshop or a theatre performance) is what recurrently feeds into the accumulation of designerly knowledge (Binder et al., 2011, pp. 118ff.).

Despite the fact that many museums today embrace commercial models of design thinking, such as IDEO (IDEOU, n.d.; see also Eid, this volume) not many engage with design as a systematic form of research and a specific form of knowledge formation. Although design scholars have increasingly developed tools for analysing and understanding participatory design processes also with a distinct focus on museums activities, exhibitions and their users, design-based research has rarely made its way to the field of museology. In applying thing-ing in a systematic fashion, museology may benefit from a closer encounter with developments in practice-based design research and design anthropology (Gunn et al., 2013; Koskinen et al., 2011; Vaughan, 2017). This approach usefully emphasises the value of moving design from 'the lab' to 'the field,' conducting embedded design research and systematic, iterative design experiments and using these experiments as tools of knowledge-formation and theory-building (Markussen, 2017).

The editors have been given a unique opportunity to explore and evaluate practice-based co-design and design-based research on a large scale. From 2016 to 2020 we were part of the Our Museum research and development programme (Our Museum, n.d.), which may be the largest collaborative research programme on museum communication on a global scale. Funded by the VELUX FOUNDATIONS and the Nordea-fonden, the programme included 35 museum professionals and university researchers collaborating on 13 different projects, each of which explored how museums, now and in the past, can facilitate cultural citizenship by co-creation of new modes of communication. Eight projects were based on a 'design-anthropological' approach (Gunn et al., 2013) where the key researcher works in 'the field' of a museum institution over a sustained period of time as part of the exhibition or communication team. In that way, each project could draw on knowledge generated from working 'behind the scenes' (Macdonald, 2002) at a particular museum institution, co-constructing particular exhibitions or communication strategies and analysing and evaluating user interactions. In this way, each project got first-hand knowledge of how particular representations worked for which groups of users, and hence why certain strategies were successful in facilitating users' cultural citizenship (see the contribution from Nicolaisen et al., this volume). Moreover, by generating 'designerly' project knowledge of particular design ecologies in tandem with joint seminar discussions of processes and results across projects the programme combined designerly and scholarly modes of knowledge formation. As a result, systematic design of museum communication co-evolved with analytical museum research based on practical involvement and commitment. 
With this volume, we aim to widen and compare the Our Museum programme approach by casting the net as wide as possible in geographical, topical and institutional terms, thus hopefully solidifying the knowledge base on which to establish a set of guidelines and suggestions for future museology and museum practices, which we address in the final chapter of this volume.

\section{Contributions and chapter overview}

As argued previously, experimental approaches are applied both in museology and museum practice as ways of working creatively with museum communication and user empowerment are evolving across the museum field globally and flourishing in a diversity of forms. As such this volume does not pretend to deliver a final manual for how to further this trend. Rather, the ensuing chapters explore the diversity of experiments conducted and the various implications such processes have for our understanding of contemporary and future museum practices, particularly when it comes to reconfiguring relations between institutions, representations and users. Hence, the volume will document and discuss cuttingedge examples of how museums design, apply and assess new modes of audience engagement, participation and co-creation. It does so by critically scrutinising concrete cases of innovative endeavours to redefine museological practice within museums focusing on the redesign of institutions, representations and user relations. Volume authors are all scholars experienced in practice-based museum design and they represent a range of theoretical and empirical traditions, thus providing both range of orientation and depth of insight to the field. Taken together, the volume chapters will illuminate results across a diversity geographical contexts (Europe, North and South Americas), fields and museums - from science centres, cultural-historical museums and art galleries - thus building a reflexive repository of design practices, experiments and experiences that can help strengthen future museum research and design.

Reflecting on the vision of curator G. B. Goode of the Smithsonian Institute, U.S.A. in 1889 that the museum in the future would 'stand side by side with the library and the laboratory' Sarah Kenderdine (Chapter 1) reflects on the potential of museums as 'thinking machines' with a particular emphasis on the role of immersive visualisation especially as an intermediary between big data, digital archives, gallery spaces and other physical locations as well as modes of networked access. Drawing on her work with the Laboratory for Experimental Museology, Lausanne, and ongoing empirical experiments in museum practice, she explores how museums can make computation experiential, spatial and materialised, embedded and embodied. Also with an emphasis on visualisation, Rodrigo Tisi Paredes, in Chapter 2, discusses how visualisation and immersive environments can be used to stage 'impossible objects.' Based on a reading of museums as performance spaces, he reflects on experimental design of two exhibitions developed in collaboration between MESS, a collaborative platform for designers, architects, engineers, sociologists and other professionals, and the Museo Chileno 
de Arte Precolombino (The Chilean Museum of Pre-Columbian Art) in Santiago de Chile. Both examples worked in different ways to make pre-Colombian embodied and material heritage present (e.g. through video-holographic mediated 'interaction' between pre-Columbian indigenous people and contemporary museum-goers) and show how immersive exhibition spaces can evoke presence, make objects that cannot be physically transported to the rooms of the museum present to viewers, and finally introduce collaborative processes of creation.

In Chapter 3, Jennifer Carter and Christina Lleras address how recent and painful pasts can be incorporated into the plans of a yet-to-come Museum of Memory in Bogotá, Columbia. Illuminating clear and formulated intentions by the staff of playing an institutional role for the understanding of the traumatic civil war that has tormented the country and thereby activate their individual and collective senses of responsibility and agency toward political intervention, Carter and Lleras consider how the planning team of a national museum-in-the-making as yet unconstrained by the realities of the everyday functioning of a bricks-andmortar building - imagined a Colombian memorial museum coming-into-being through the lens of this thinking; and they ask: what happens when process becomes praxis? Along related lines, Erika Grasso and Gianluigi Mangiapane, in Chapter 4, analyse the innovative institutional role of a museum, closed to the public. The Museum of Anthropology and Ethnography at the University of Turin has been closed to the public since 1984. Yet, it has implemented various participatory practices and audience engagements/development projects. The chapter illustrates two related initiatives. The first focused on connecting with young, second-generation immigrants and the Turin LGBTQ community, while the second initiative harnessed the resources of West African diaspora groups as part of museum education and exhibition design. Based on these analyses, the authors discuss how the initiatives have enabled the museum to reflect on its future social and political role.

Shifting focus to representations of natural heritage as part of an immersive display, Rodanthi Tzanelli, in Chapter 5, asks how museums working in a consumerist economy can still fulfil a mission to educate audiences. Mostly advertised as a family leisure attraction, Tropical World in Leeds, UK, offers a repository of flora and fauna from extinguishing species residing originally in colonised regions, and is now home to the largest collection of tropical plants outside Kew Gardens, London. With a focus on the global aesthetic potential of nature, which simultaneously advocates an ethical order of cross-generational sustainability, the garden facilitates a multisensory walk into future potentialities regarding environmental protection that also contains potentials for building new pedagogies of feeling, dialogue and responsibility. Similarly, Mieke Bal, in Chapter 6, departs from a critical and ethical reflection on current consumerist strategies in the museum field. Drawing on the author's successful curation of an exhibition at the Munch Museum in Oslo, Norway, the chapter aims to help advance future visitor experiences in museums by exploring and re-theorising notions of time. Departing from ideas of linear time as constitutive of user experiences at the museum, Bal 
considers how shock effects in the exhibition can offer a strategy for challenging museum audiences' position as passive consumers. Hence, the chapter documents how museums may experiment with ways of combining artworks in the museum so that they offer different viewer experiences from those found in mainstream art museums.

Turning back to a view of the institutional role of museums in evaluating and learning from experiments with dissemination of art to the public, Wescley Xavier, Diana Castro and Vanessa Brulon, in Chapter 7, reflect on evidence from three Brazilian museums, The Museum of Conspiracy (Museu da Inconfidência) and Casa dos Contos Museum, located in Ouro Preto (a UNESCO world heritage site), and the Rio Art Museum (MAR). The authors point out that museums perform a dual role. They can be places of cultural reinforcement and mechanisms of distinction, legitimacy and maintenance of consensus and appropriation of the city. Yet, they also have the potential to make users conscious of the very same mechanisms and of contradictions present in cultural spaces and in everyday life. In Chapter 8, Haitham Eid relates the concept of experimental museology to parallel discussions of 'experimental innovation' as an emerging framework in business practice that promotes the expansion of internal experimentations across all organisational levels, and he investigates its prospects for cultural heritage institutions and museums. Through practical examples from the museum field in Australia, the United States and the United Kingdom, the chapter examines various experimental innovation models that encourage creativity among museum staff and advance museums as viable and relevant cultural organisations in society.

In Chapter 9, Palmyre Pierroux, Birgitte Stauge and Rolf Steier invite us further into the museum as a research space for collaborative experimentation. The chapter presents an exhibition experiment at the National Museum of Art, Architecture and Design in Oslo, Norway, in which museum curators and educators, university researchers and an architectural firm collaboratively explored the design and use of virtual reality. Drawing on theories of co-design and participatory design the chapter proposes a new model of multi-professional collaboration in museum practice. The model is based on the authors' examination of the partners' collaborative process with a particular focus on how their respective interests co-evolved over a one-year period of workshops, meetings and mockups, culminating in a full-scale implementation of an exhibition. Also focusing on curator-academic collaboration, Line Nicolaisen, Marianne Achiam and Tina Ibsen, in Chapter 10, examine how science museums may go beyond putting science on display, by purposefully deconstructing scientific knowledge, values and practices and reconstruct these to create environments that appeal to more diverse groups of users. The chapter examines this de-/reconstruction process through the development of an award-winning exhibition Made in Space at the Tycho Brahe Planetarium, Copenhagen, Denmark, an exhibition specifically designed to be inclusive to users across the gender spectrum. The authors trace the adaptive transformations of established astrophysics knowledge, values and practices as these progress through a series of workshops involving astrophysicists, 
designers and education researchers to finally become embodied in the exhibition. A similar focus on participatory design processes marks Chapter 11, by Anne Scott Sørensen. She considers how participatory design can be applied as a contextualised platform for museum experimentation. Through a case study of a current initiative at The Workers' Museum in Copenhagen, Denmark, Sørensen explores three examples of and participatory design in museum communication: Activist! (an exhibition), Museum Rebels (a partnership with young activists) and the Protest Workshop (an installation and learning centre established during the exhibition) all pointing to the need for elaborate feedback mechanisms and more explicit formulation of outcomes that are relevant to, and can be recognised by, the participants who contributed.

While each chapter in this volume explores experimental museology and museum practices from very different angles, the final, editorial chapter, reflects on commonalities and perspectives across volume sections and chapters in order to provide a set of general guidelines for future experimental museology. Noting the relational, transformational and processual character of the term, the chapter illuminates the necessity for museums to adopt such dimensions into daily practice in order to not only meet the demands of complex communities and often contradictory obligations but to help shape future directions.

\section{Note}

1 The first wave of museology was generated within the disciplinary pillars of museum practice (art, archaelogy, history and so on). The second wave, the 'new museology,' stressed the institutional role of museums in relation to power and identity, while the third wave stressed museums as catalysts of dialogue and societal action.

\section{References}

Binder, T., De Michelis, G., Ehn, P., Jacucci, G., Linde, P., \& Wagner, I., (2011). Design things. The MIT Press.

Bishop, C. (2014). Radical museology. Walther Konig.

Bjerregaard, P. (2019). Exhibitions as research: Experimental methods in museums. Routledge.

Blüdnikow, B. (2017). Det skal være vildt og udfordrende [It must be wild and challenging]. Berlingske, 24 April. Interview with director Rane Willerslev. https://www. berlingske.dk/kultur/det-skal-vaere-vildt-og-udfordrende

Cross, N. (2007). Designerly ways of knowing. Birkhäuser.

Dewdney, A., Dibosa, D., \& Walsh, V. (2013). Post-critical museology. Routledge.

Drotner, K., Dziekan, V., Parry, R., \& Schrøder, K. C. (Eds.). (2018). The Routledge handbook of museums, media and communication. Routledge.

Drotner, K., \& Schrøder, K. (2013). Museum communication and social media: The connected museum. Routledge.

Falk, J. H., \& Dierking, L. D. (2013). The museum experience revisited. Routledge.

Falk, J. H., \& Sheppard, B. K. (2006). Thriving in the knowledge age: New business models for museums and other cultural institutions. Altamira Press.

Gunn, W., Otto, T., \& Smith, R. C. (2013). Design anthropology: Theory and practice. Bloomsbury. 
Heller, M., Scholz, A., \& Wegner, A. (2015). The laboratory concept: Museum experiments in the Humboldt Lab Dahlem. Nicolaische Verlagsbuchhandlung.

Hooper-Greenhill, E. (1992). Museums and the shaping of knowledge. Routledge.

ICOM. (25 July, 2019). ICOM announces the alternative museum definition that will be subject to vote. https://icom.museum/en/news/

IDEOU. (n.d.). Build relevant skills for the modern world. https://www.ideou.com

Janes, R. R., \& Sandell, R. (2019). Museum activism. Routledge.

Knell, S. J., MacLeod, S., \& Watson, S. (Eds.). (2007). Museum revolutions: How museums change and are changed. Routledge.

Koskinen, I., Zimmerman, J., Binder, T., Redstrom, J., \& Wensveen, S. (Eds.). (2011). Design research through practice: From the lab, field and showroom. Morgan Kaufmann.

Macdonald, S. (2002). Behind the scenes at the science museum. Berg.

Macdonald, S. (2007). Interconnecting: Museum visiting and exhibition design. CoDesign: International Journal of CoCreation in Design and the Arts, 3, 149-162.

Macdonald, S., \& Basu, P. (2007). Exhibition experiments. Blackwell.

Markussen, T. (2017). Building theory through design. In L. Vaughan (Ed.), Practice-based design research (pp. 87-98). Bloomsbury Academic.

Our Museum. (n.d.). www.ourmuseum.dk

Rentschler, R., \& Hede, A.-M. (2015). Museum marketing. Routledge.

Schrøder, K. C. (2018). Audience reception. In Philip M. Napoli (Ed.), Mediated communication (pp. 105-128). De Gruyter Mouton.

Shelton, A. (2013). Critical museology: A manifesto. Museums worlds: Advances in research, $1(1), 7-23$.

Simon, N. (2010). The participatory museum. Museum: 2.0.

Simon, N. (2016). The art of relevance. Museum: 2.0.

Treagust, D. F., Won, M., \& Duit, R. (2014). Paradigms in science education research. In N. G. Lederman \& S. C. Abell (Eds.), Handbook of research on science education (pp. 3-17). Routledge.

Tzortzi, K. (2015). Museum space: Where architecture meets museology. Routledge.

Vaughan, L. (Ed.). (2017). Practice based design research. Bloomsbury.

Vergo, P. (1989). The new museology. Reaktion Books.

Weibel, P., \& Latour, B. (2007). Experimenting with representation: Iconoclash! and Making Things Public. In S. Macdonald \& P. Basu (Eds.), Exhibition experiments (pp. 94-108). Blackwell.

Weil, S. E. (1999). From being about something to being for somebody: The ongoing transformation of the American Museum, Daedalus, 128(3), 229-258. 